\title{
Nutrient Losses during Winter and Summer Storage of Separated and Unseparated Digested Cattle Slurry
}

\author{
Francesca Perazzolo, ${ }^{*}$ Gabriele Mattachini, Elisabetta Riva, and Giorgio Provolo
}

\begin{abstract}
Management factors affect nutrient loss during animal manure slurry storage in different ways. We conducted a pilot-scale study to evaluate carbon $(\mathrm{C})$ and nitrogen $(\mathrm{N})$ losses from unseparated and digested dairy slurry during winter and summer storage. In addition to season, treatments included mechanical separation of digestate into liquid and solid fractions and bimonthly mixing. Chemical analyses were performed every 2 wk for the mixed materials and at the start and end of storage for unmixed materials. The parameters examined allowed us to estimate $\mathrm{C}$ and $\mathrm{N}$ losses and examine the factors that determine these losses as well as emission patterns. Gas measurements were done every 2 wk to determine the main forms in which gaseous losses occurred. To evaluate the effect of separation, measured losses and emissions of separated liquid and solid fractions were mathematically combined using the mass separation efficiency of the mechanical separator. Nutrient losses were mainly affected by climatic conditions. Losses of C (up to $23 \%$ ) from unseparated, unmixed digestate and of $\mathrm{N}(38 \%$ from combined separated fractions and from unseparated digestate) were much greater in summer than in winter, when $\mathrm{C}$ and $\mathrm{N}$ losses were $<7 \%$. Mixing tended to significantly increase $\mathrm{N}$ losses $(P<0.1)$ only in winter. Mechanical separation resulted in lower GHG emissions from combined separated fractions than from unseparated digestate. Results indicate that to maximize the fertilizer value of digested slurry, dairy farmers must carefully choose management practices, especially in summer. For separated digestates, practices should focus on storage of the liquid fraction, the major contributor of $\mathrm{C}$ and $\mathrm{N}$ losses (up to 64 and $90 \%$ of total losses, respectively) in summer. Moreover, management practices should limit $\mathrm{NH}_{3}$, the main form of $\mathrm{N}$ losses (up to $99.5 \%$ ).
\end{abstract}

\section{Core Ideas}

- Season had the most significant effect on $\mathrm{N}$ and $\mathrm{C}$ losses during slurry storage.

- Mechanical separation did not significantly affect $\mathrm{N}$ and $\mathrm{C}$ losses.

- In summer, temperature caused losses of up to $38 \%$ of TKN and $23 \%$ of TOC from digested slurry.

- $\mathrm{CO}_{2}$ and $\mathrm{NH}_{3}$ were the predominant gaseous forms of $\mathrm{C}$ and $\mathrm{N}$ losses.

Copyright $\odot$ American Society of Agronomy, Crop Science Society of America, and Soil Science Society of America. 5585 Guilford Rd., Madison, WI 53711 USA. All rights reserved.
$\mathrm{M}$ ANURE SLURRIES from dairy and other livestock production systems are valuable sources of plant nutrients and carbon $(\mathrm{C})$ and are thus a resource for crop producers. Slurry use as fertilizer should be based on its nutrient and $\mathrm{C}$ content (considering potential nitrogen $[\mathrm{N}]$ and $\mathrm{C}$ losses during on-farm storage) to reduce negative environmental impacts (Misselbrook et al., 2016). Losses of $\mathrm{N}$ and $\mathrm{C}$ as ammonia $\left(\mathrm{NH}_{3}\right)$, nitrous oxide $\left(\mathrm{N}_{2} \mathrm{O}\right)$, and methane $\left(\mathrm{CH}_{4}\right)$ during slurry storage are particularly relevant (Chadwick et al., 2011; Dinuccio et al., 2012) and should be evaluated and minimized via cost-effective mitigation methods.

Using the integrated modeling tool MITERRA-EUROPE, Oenema et al. (2007) estimated that in the EU almost $30 \%$ of the $\mathrm{N}$ excreted in dairy barns is lost during storage. Approximately $63 \%$ of the loss was via $\mathrm{NH}_{3}$ emissions; $23 \%$ was lost following nitrification or denitrification as nitric oxide $(\mathrm{NO}), \mathrm{N}_{2} \mathrm{O}$, and $\mathrm{N}_{2}$; and $13 \%$ was lost due to leaching and run-off. However, the differences in mean $\mathrm{N}$ losses from manure storages among countries were large (ranging from 20 to 35\%). Previous studies highlighted that $\mathrm{N}$ losses from stored livestock wastes vary widely. For example, stored liquid slurry can lose 8 to $30 \%$ in 4 to 6 mo (Amon et al., 2006; Patni and Jui, 1991; Sommer et al., 2013), and manure heaps can lose 10 to $50 \%$ of the initial $\mathrm{N}$ in 3 to 4 mo (Chadwick, 2005; Hansen et al., 2006; Petersen and Sorensen, 2008; Tran et al., 2011; Webb et al., 2012).

For liquid material, $\mathrm{N}$ losses may occur almost entirely $(>99 \%$ as reported by Perazzolo et al., 2015) as $\mathrm{NH}_{3}$ because the nitrification process in the storage environment is practically absent (Fangueiro et al., 2008; Patni and Jui, 1991). For solid fractions, significant $\mathrm{NH}_{3}$ losses occur along with losses of $\mathrm{N}_{2} \mathrm{O}$ and other gaseous $\mathrm{N}$ forms following denitrification. Webb et al. (2012) reported $\mathrm{N}_{2} \mathrm{O}$ emission estimates for cattle and pig manure that were 0.1 to $0.9 \%$ of total $\mathrm{N}$. Nitrate loss in seepage water from storage heaps can also occur, especially if aerobic conditions are established inside the heap (Dinuccio et al., 2008; Sommer et al., 2013).

Carbon loss from manure storage mainly occurs as emissions of $\mathrm{CO}_{2}$ and $\mathrm{CH}_{4}$, which pose a concern in terms of increasing atmospheric greenhouse gas (GHG) concentrations and also represent a loss of energy fertilizer value (Petersen and Sorensen,

Dep. of Agricultural and Environmental Sciences, Univ. degli Studi di Milano, Via
Celoria 2, 20133 Milano, Italy. Assigned to Associate Editor Heidi Waldrip.

Abbreviations: $\mathrm{CO}_{2 e q^{\prime}} \mathrm{CO}_{2}$ equivalents; $\mathrm{GHG}$, greenhouse gas; PVC, polyvinyl chloride; TAN, total ammoniacal nitrogen; TKN, total Kjeldahl nitrogen; TOC, total organic carbon; TS, total solids; VFA, volatile fatty acid; VS, volatile solids. 
2008). Previous studies found C losses of 14 to $50 \%$ from slurry stores (Amon et al., 2007; VanderZaag et al., 2010a, 2010b) and 35 to $70 \%$ from manure heaps (Chadwick, 2005; Petersen and Sorensen, 2008; Tittonell et al., 2010). The $\mathrm{CH}_{4}-\mathrm{C}$ losses from manure heaps can range from $0.4 \%$ to $10 \%$ of total C (Chadwick, 2005; Webb et al., 2012) but can represent as much as 60 to $70 \%$ of total $\mathrm{C}$ in raw slurry stores under warm storage conditions (Moset et al., 2012).

Treatments such as solid-liquid separation and anaerobic digestion alter the characteristics of raw slurry; consequently, the losses of $\mathrm{N}$ and $\mathrm{C}$ from stored slurries that have undergone treatment may be quite different than those from raw (untreated) slurry. Mechanical separation of slurry is widely used on livestock farms (Burton and Turner, 2003). Furthermore, slurry management systems that produce biogas from anaerobic digestion, followed by mechanical separation of digestate, are now common in Europe, especially in those zones in which the high livestock density produces excessive quantities of nutrients that should be treated with energyconsuming technologies (e.g., northern Italy). Therefore, nutrient losses during storage of separated fractions of co-digested slurries (which have been treated with other biomass during anaerobic digestion) should be considered both to improve the accuracy of on-farm $\mathrm{N}$ and $\mathrm{C}$ balance evaluations and to better assess the potential negative impact of such losses on the environment. Most previous studies evaluated $\mathrm{N}$ and $\mathrm{C}$ losses from stored slurry or digestate, but very little published information is available on nutrient losses from the storage of separated fractions of co-digested slurry.

To improve our knowledge on this aspect of slurry management, the aim of this research was (i) to evaluate the effect of different management options on $\mathrm{C}$ and $\mathrm{N}$ losses from a cattle co-digested slurry (digestate) and its mechanically separated solid and liquid fractions during storage and (ii) to determine the main forms in which the gaseous losses occur. We investigated the effect of two storage practices (pilot-scale simulated storage tanks subjected to periodic mixing or left unmixed) on $\mathrm{N}$ and $\mathrm{C}$ contents of raw and mechanically separated digestate (liquid and solid fractions) during $90 \mathrm{~d}$ of outdoor storage in two different periods, representing winter and summer seasons. The mixing treatment was studied to consider the effect of manure disturbance that normally occurs at farm facilities. The air-liquid and the air-solid interfaces of manure (and therefore emissions) are affected on numerous occasions by the addition of manure, mixing of slurry, emptying of storage tanks during land spreading, and rain entering the storage tanks.

\section{Material and Methods}

The study was conducted at the A. Menozzi Experimental Farm of the University of Milan (Landriano, Italy; $45^{\circ} 19^{\prime} 16.5^{\prime \prime} \mathrm{N}, 9^{\circ} 15^{\prime} 56.4^{\prime \prime} \mathrm{E}$ ) over two time periods. The first period (winter) extended from 1 Nov. 2013 to 30 Jan. 2014. The second period (summer) extended from 2 May 2014 to 31 July 2014.

\section{Design of Pilot-scale Storage Facility}

A pilot-scale storage facility was designed and constructed with the aim of providing accurate and reproducible data on $\mathrm{N}$ and $\mathrm{C}$ losses and gaseous emissions from anaerobically digested slurry and from its mechanically separated liquid and solid fractions. The facility was situated in an open field $30 \mathrm{~m}$ from the nearest barn. The storage system consisted of eight stainless steel cylindrical storage units (OscarInox 1000, Toscana Inox) for the digested slurry and its liquid fraction and four square containers constructed of heavy-duty polyvinyl chloride (PVC) and polyester that had triple-layer side walls enclosed in a metal frame (Bestway s.r.l., Milano, IT) for the solid digestate fraction. Each cylindrical storage unit was $1.25 \mathrm{~m}$ high and $1.02 \mathrm{~m}$ in diameter $\left(1.02 \mathrm{~m}^{3}\right.$ total capacity) (Fig. 1). Each square container was $0.31 \mathrm{~m}$ high and $1.22 \mathrm{~m}$ in length and width, with a maximum storage capacity of $0.7 \mathrm{~m}^{3}$ of solids. All 12 storage units were positioned on the ground level and without lids or other covering, to allow full exposure of the contents to the ambient climate. An office located next to the storage units housed equipment for monitoring gaseous emissions from the storage units, discussed below. During each sampling day, photographs of the surface layer of all the materials were taken (data not shown) and observations about the conditions (crust absence or presence, dry or wet, etc.) were recorded to better interpret the results obtained from mass balance and flux measurements.

\section{Slurry and Storage Management}

Digestate was collected from an anaerobic digester $(250 \mathrm{~kW}$ of electric power installed) at a nearby commercial dairy farm (Lodi Vecchio, Italy). The digester feedstock consisted of $90 \%$ cattle slurry and $10 \%$ corn silage, and digestate was mechanically separated using a roller press (made by Rota Guido S.R.L., Cremona, Italy) that generated a liquid fraction and a solid fraction. Mechanical separation occurred on the commercial farm $24 \mathrm{~h}$ before the start of each experimental storage period.

Each manure type (unseparated digestate, liquid fraction, and solid fraction) was tested in duplicate in treatments that consisted of two different storage practices: (i) periodic mixing and (ii) no mixing. Each experimental period lasted $90 \mathrm{~d}$ and represented summer and winter seasons in the region. At the

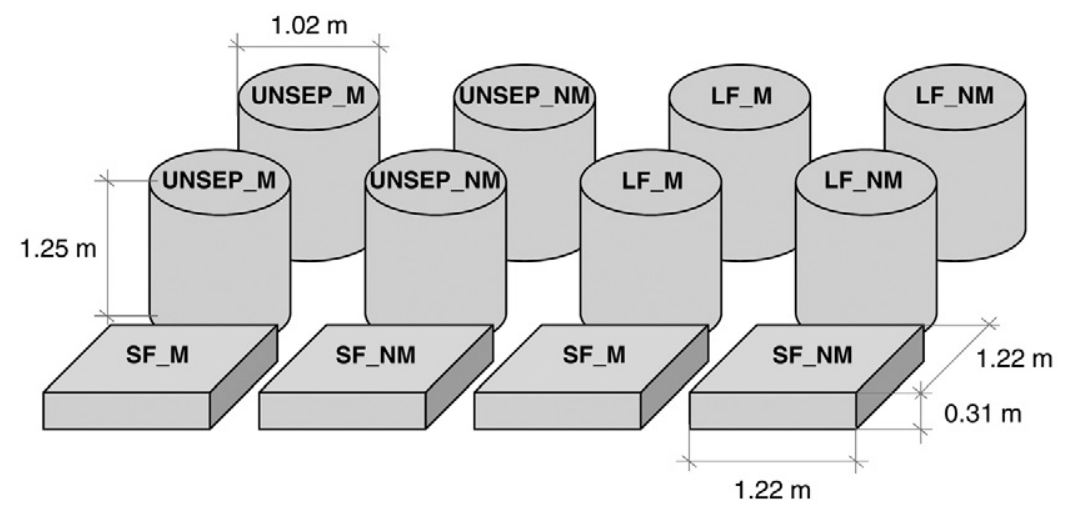

Fig. 1. Pilot-scale storage complex, with eight cylindrical storage units for digested slurry and its liquid fraction and four square storage units for the solid fraction. Samples type were anaerobically digested cattle slurry that was mixed (UNSEP_M) and unmixed (UNSEP NM); liquid fraction of mechanically separated digested slurry that was mixed (LF M) and unmixed (LF NM); and solid fraction of digested slurry that was mixed (SF_M) and unmixed (SF_NM). 
beginning of each experiment, the eight (four per slurry type) cylindrical storage units were filled with liquid slurries (four with unseparated digestate and four with the liquid fraction) to 0.95 $\mathrm{m}$ depth, corresponding to $0.8 \mathrm{~m}^{3}$ in each container. Likewise, the four square containers were filled with the solid fraction to obtain a trapezoidal pile (height of $1 \mathrm{~m}$ ) corresponding to $250 \mathrm{~kg}$ each (Fig. 1). For the mixing treatment, containers of unseparated and liquid fraction were thoroughly stirred from the bottom to the top with a mixer (approximately $50 \mathrm{rpm}$ ) for about 6 min once every $2 \mathrm{wk}$; similarly, solid fraction containers were manually thoroughly mixed with a shovel. This treatment was designed to evaluate the effect of operations normally used in managing full-scale manure storage on farms. For the unmixed treatment, no mixing was conducted.

\section{Temperature Measurement and Climate Data}

The temperature in each container was recorded every 30 min throughout each storage period using a temperature sensor (TMC6-HD, Onset Computer Cor.) located $0.3 \mathrm{~m}$ beneath the surface of the container contents. The sensors were connected to a data logger (HOBO U12-006, Onset Computer Corp.), which was connected to a computer. Climatic data (air temperature, air humidity, precipitation, wind speed and direction, and barometric pressure) were obtained using two portable climate stations (Vantage Pro2 Station, Davis Instruments Corp.), which were installed $1.8 \mathrm{~m}$ above the container base. Climatic data were recorded every $5 \mathrm{~min}$ throughout each storage period. Daily average (mean, maximum, and minimum temperatures) values were then calculated. Evaporation was estimated by monitoring the levels of liquid materials in the storage vessels.

\section{Manure Analyses and Nutrient Losses}

One 0.5-L sample from each container was collected at the start and end of each storage period (when it was possible to mix all the containers), for a total of 12 samples at the start and 12 at the end. Samples of periodically mixed digestate, liquid fraction, and solid fraction were also taken once every $14 \mathrm{~d}$ (for a total of six times) throughout the storage periods (the total number of samples was 36: 12 for mixed digestate, 12 for mixed liquid fraction, and 12 for mixed solid fraction). The sampling procedure was designed to collect subsamples of slurry at different depths, then to combine and mix the individual subsamples in a container, from which a representative sample of $0.5 \mathrm{~L}$ was withdrawn for analysis. The samples were analyzed for total solids (TS), volatile solids (VS), total Kjeldahl nitrogen (TKN), total ammoniacal nitrogen (TAN), $\mathrm{pH}$, volatile fatty acids (VFAs), and total organic carbon (TOC) according to standard methods (APHA, AWWA, and WEF, 2012). At the beginning and end of each storage period, phosphorus $(\mathrm{P})$ content was measured using inductively coupled plasma mass spectrometry (APHA, AWWA, and WEF, 2012). All parameters were expressed as averaged results from duplicates for each material.

During each sampling day, slurry level (for mass balance calculation) and $\mathrm{pH}$ (at 10-cm depth) were measured in unseparated and liquid fraction treatments. The solid fractions were weighed at the beginning and end of the storage periods. Mass losses of $\mathrm{C}$ and $\mathrm{N}$ were expressed as percentages of their initial values. To evaluate the effect of separation, $\mathrm{C}$ and $\mathrm{N}$ contents of separated liquid and solid fractions were mathematically combined (Fangueiro et al., 2008) using the mass separation efficiency $(10.9 \pm 2.1 \%)$ of the mechanical separator, calculated as reported in Cocolo et al. (2016).

Because obtaining a representative sample from the solid fraction of most wastes is typically problematic, the nonvolatile element $\mathrm{P}$ was used as an internal reference (Petersen and Sorensen, 2008) to correctly evaluate the losses of $\mathrm{C}$ and $\mathrm{N}$ from the solid fraction.

The losses of $\mathrm{C}$ and $\mathrm{N}$ from the three sample types were calculated using Eq. [1]:

$\mathrm{LO}=M \times\left[\left(X_{\text {fresh }}-X_{\text {after storage }}\right) \times\left(P_{\text {fresh }} / P_{\text {after storage }}\right)\right]$

where $\mathrm{LO}$ is the mass loss of $\mathrm{C}$ or $\mathrm{N}(\mathrm{g}) ; M$ is the mass $(\mathrm{kg})$ of the material being stored (unseparated digestate, liquid fraction, solid fraction, mathematically combined separated fractions); $P_{\text {fresh }}$ is the phosphorus concentration at the beginning of storage; $P_{\text {affer storage }}$ is the phosphorus concentration at the end of storage; and $X$ is the $\mathrm{C}$ or $\mathrm{N}$ concentration $\left(\mathrm{g} \mathrm{kg}^{-1}\right)$ at the beginning $\left(X_{\text {fresh }}\right)$ and end $\left(X_{\text {affer storage }}\right)$ of storage.

The mass of liquid manures was estimated from the measured tank levels; the mass of the solid samples was determined by weighing. Recovery of $\mathrm{P}$ was between 98 and 101\%.

\section{Flux Measurements}

To understand the composition of the emissions to air, flux measurements were made every $2 \mathrm{wk}$ during each storage period. Gaseous emissions $\left(\mathrm{CO}_{2}, \mathrm{CH}_{4}, \mathrm{NH}_{3}\right.$, and $\left.\mathrm{N}_{2} \mathrm{O}\right)$ from the surface of each storage container were measured using a dynamic chamber method (Dinuccio et al., 2008; Petersen et al., 2012). Emissions were collected using funnel systems (Balsari et al., 2007) floated on the liquid or placed on the solid surfaces at the center of each storage unit. Each collection system consisted of a PVC funnel fixed on four PVC spherical floats, covering $0.07065 \mathrm{~m}^{2}$ of surface area. Airflow through the system was set at $9 \mathrm{~L} \mathrm{~min}^{-1}$. The $\mathrm{NH}_{3}$ emissions were collected using acid traps filled with $1 \%$ boric acid for a period of $8 \mathrm{~h}$ for each container (Perazzolo et al., 2015). Emissions of $\mathrm{CO}_{2}, \mathrm{CH}_{4}$, and $\mathrm{N}_{2} \mathrm{O}$ were determined using a 1302 Innova photoacoustic gas monitor (Innova AirTech Instruments) as in Perazzolo et al. (2015), with two 40-min sampling periods each day. The samples from the different containers were taken sequentially at two different times during the day (in the daytime hours) to ensure all samples were obtained under similar environmental conditions and yielded an average of at least six to eight stable values for each container per sampling day. Wind velocity during flux sampling was always lower than $0.1 \mathrm{~m} \mathrm{~s}^{-1}$; thus, wind interference with the measurements was considered negligible. To evaluate the emissions of GHGs in terms of $\mathrm{CO}_{2}$ equivalents $\left(\mathrm{CO}_{2 \mathrm{eq}}\right)$, conversion factors of 298 and 34 for a 100-yr time horizon were applied to $\mathrm{N}_{2} \mathrm{O}$ and $\mathrm{CH}_{4}$ emissions, respectively (Myhre et al., 2013). Carbon dioxide was not included in the calculation of total GHG emissions because it is not produced from the combustion of nonrenewable fuel (Sommer et al., 2013).

\section{Statistical Analysis}

The chemical parameters obtained (TKN, TAN, VS, TS, VFA, and TOC) at each sampling day from periodically mixed 
containers were compared using the following statistical model (Tran et al., 2011):

$Y=\mu+M_{i}+T_{j}+(M \times T)_{i j}+\varepsilon_{i j}$

where $Y$ is the parameter of interest, $\mu$ is the overall mean of measured values $\left(\mathrm{g} \mathrm{kg}^{-1}\right), M_{i}$ is the effect of mechanical separation (where $i=1,2$ for unseparated and separated slurries), $T_{j}$ is the effect of sampling time (where $j=1,2,3,4,5,6,7$ based on the number of the sampling), $(M \times T)_{i j}$ is the interaction effect, and $\varepsilon_{i j}$ is the random error (Tran et al., 2011). These data were analyzed using multifactor ANOVA (PROC GLM of SAS; SAS Institute, 2011) as in Tran et al. (2011). Datasets from the two seasonal experiments were analyzed separately because the initial concentrations of the manures stored were not comparable, even though the samples were collected from the same facility.

To assess the effect of season and mixing, statistical analysis was performed on TKN and TOC losses and expressed as percentage of the initial content so that comparable values would be analyzed in the two time periods. The following model (Tran et al., 2011) was used:

$$
\begin{aligned}
Y= & \mu+M_{i}+D_{j}+S_{k}+(M \times S)_{i k}+(D \times S)_{j k} \\
& +(M \times D)_{i j}+(M \times D \times S)_{i j k}+\varepsilon_{i j k}
\end{aligned}
$$

where $Y$ is the parameter of interest; $M_{i}$ is the effect of mechanical separation (where $i=1,2$ for unseparated and separated slurries); $D_{j}$ is the effect of mixing (where $j=1,2$ for mixed and unmixed slurries); $S_{k}$ is the effect of season (where $k=1,2$ for winter and summer); $(M \times S)_{i k},(D \times S)_{j k},(M \times D)_{i j}$, and $(\mathrm{M} \times \mathrm{D} \times \mathrm{S})_{i j k}$ are the interactions; and $\varepsilon_{i j k}$ is the effect of random error. A multifactor ANOVA (PROC GLM of SAS [SAS Institute, 2011]) was also used.

The flux data were not normally distributed with equal variance (according to Kolmogorov-Smirnov and Shapiro-Wilk tests, $\alpha=0.05)$. Thus, the effects of mechanical separation (unseparated digestate vs. mathematically combined separated fractions), season (winter vs. summer), and disturbance (mixed vs. unmixed) were evaluated using a Wilcoxon Signed Ranks nonparametric paired $t$ test analysis (PROC UNIVARIATE [SAS Institute, 2011]) to analyze $\mathrm{NH}_{3}, \mathrm{~N}_{2} \mathrm{O}, \mathrm{CH}_{4}, \mathrm{CO}_{2}$, and $\mathrm{CO}_{2 \mathrm{eq}}$ fluxes, following the procedure of Perazzolo et al. (2015). Season was considered an overall effect, and disturbance and mechanical separation were considered jointly as a combined effect. $P$ values less than 0.05 were considered statistically significant in all tests.

\section{Results and Discussion}

\section{Ambient Environmental Conditions and Manure \\ Temperatures}

The temperature profiles throughout the experiment differed across the two storage periods (data not shown). For the winter period (average $6.5^{\circ} \mathrm{C}$; maximum $18.1^{\circ} \mathrm{C}$; minimum $-0.4^{\circ} \mathrm{C}$ ), the temperature decreased during the first $50 \mathrm{~d}$, after which it remained relatively stable between 3 and $7^{\circ} \mathrm{C}$ until the end of storage at $90 \mathrm{~d}$. The average temperatures for the unseparated digestate, liquid fraction, and solid fraction were 7.7, 8.7, and $10.6^{\circ} \mathrm{C}$, respectively, without significant differences between mixed and unmixed treatments. In contrast, temperatures during the summer period were comparatively stable throughout (average $21.4^{\circ} \mathrm{C}$; maximum $27.8^{\circ} \mathrm{C}$; minimum $14.8^{\circ} \mathrm{C}$ ). The average temperatures for the unseparated digestate, liquid fraction, and solid fraction were $25.8,26.4$, and $28.9^{\circ} \mathrm{C}$, respectively, without significant differences between mixed and unseparated treatments. Total rainfall of $350 \mathrm{~mm}$ was recorded during the winter storage period and $285 \mathrm{~mm}$ during the summer storage period. These amounts were higher than normal, as averages of $224 \mathrm{~mm}$ for winter and $230 \mathrm{~mm}$ for summer are usually observed (ARPA 2015).

\section{Manure Characteristics and Changes during Storage}

Although all manure samples came from the same farm digester, the manure characteristics were slightly different for the two storage periods; this was expected because animal diet composition, feed intake, water management, and other factors at commercial dairies can change slightly over time and with specific management practices. Table 1 shows the initial and final characteristics of the materials during the two storage periods. As expected, on a weight basis, considering the characteristics of the materials at the start of the two experiments, the TS content in liquid fraction (5.12\%, average of mixed and unmixed) was lower than in unseparated digestate $(6.41 \%$, average of mixed and unmixed) and highest in solid fraction (16.45\%, average of mixed and unmixed) (Table 1). The latter is rich in organic $\mathrm{C}$ and poor in TAN (Table 1).

Figure 2 shows the variation of manure concentrations of chemical parameters obtained during each storage period. During storage, all the chemical parameters varied (Table 1). During the winter storage period, TS, VS, TKN, and TAN decreased slightly (Fig. 2) but significantly $(P<0.05)$, indicating that $\mathrm{N}$ and $\mathrm{C}$ losses are small at low temperatures. These results agree with those of Patni and Jui (1991), who found very low temporal and spatial variation of $\mathrm{N}$ in cattle slurry during winter storage.

Nitrogen contents (TAN and TKN) were also significantly affected by mechanical separation in the winter period (Table 2). During summer storage, TS, VS, TAN, TKN, and VFA were significantly affected by mechanical separation (Table 2 ), and the interactions between time of sampling and mechanical separation were significant for all the parameters analyzed. Chemical changes during summer storage showed clearer trends, especially for TKN and TAN, than those during winter storage (Fig. 2). The warm temperature promoted $\mathrm{N}$ losses from all materials. In solution the un-ionized ammonia form $\left(\mathrm{NH}_{3}\right)$ is in equilibrium with the ammonium form $\left(\mathrm{NH}_{4}^{+}\right)$; however, temperature and $\mathrm{pH}$ affect the equilibrium and dissociation constant (Sommer et al., 2013). In particular, when slurry temperature increases, a proportion of $\mathrm{NH}_{4}^{+}$is converted into $\mathrm{NH}_{3}$, which can volatize and increases the risk of $\mathrm{N}$ losses (Patni and Jui, 1991).

Figure 2 illustrates that the concentrations of VS and TS in mathematically combined separated fractions during summer were, on average, higher than in unseparated digestate, as confirmed by the statistical analysis (Table 2). However, VS and TS concentrations tended to be very similar at the beginning and at the end of the storage period, probably indicating that C losses from mathematically combined separated fractions were similar to unseparated digestate at the end of the storage period. Nitrogen emissions, however, were higher from the 
Table 1. Nutrient content (fresh weight basis) in the different materials before and after storage. Data shown are mean values with standard deviation in parentheses. $\dagger$

\begin{tabular}{|c|c|c|c|c|c|c|c|c|c|c|c|c|c|c|c|}
\hline & & TS & & /S & & AN & & $\mathrm{KN}$ & & $\mathrm{OC}$ & VFA & & $P$ & & $\mathrm{H}$ \\
\hline & & $\%$ & & $\mathrm{~g}_{\mathrm{TS}}^{-1}$ & & $\mathrm{~g}_{\mathrm{TS}}{ }^{-1}$ & & $\mathrm{~g}_{\mathrm{TS}}^{-1}$ & & -1 & $\begin{array}{c}\mathrm{mg} \mathrm{CH} \mathrm{CH}_{3} \mathrm{COOH} \\
\mathrm{kg}_{\mathrm{TS}}^{-1}\end{array}$ & & $\mathrm{~g}_{\mathrm{TS}}{ }^{-1}$ & & \\
\hline & & & & & & & inter & & & & & & & & \\
\hline Start & & & & & & & & & & & & & & & \\
\hline Unseparated mixed & 6.44 & $(0.03)$ & 742 & (8) & 31.8 & $(0.2)$ & 56.1 & $(0.2)$ & 422 & (6) & 9658 (4674) & 10.2 & $(0.2)$ & 8.10 & $(0.09)$ \\
\hline Unseparated unmixed & 6.58 & $(0.21)$ & 742 & (20) & 31.2 & $(0.8)$ & 55.8 & $(3.2)$ & 422 & (11) & $9133(3100)$ & 10.0 & $(0.3)$ & 8.07 & $(0.09)$ \\
\hline Liquid fraction mixed & 5.16 & $(0.04)$ & 705 & (6) & 38.4 & $(0.4)$ & 65.1 & $(1.0)$ & 380 & (6) & $17558(5911)$ & 12.0 & (1.9) & 8.30 & $(0.02)$ \\
\hline Liquid fraction unmixed & 5.08 & $(0.01)$ & 703 & (6) & 38.9 & $(0.6)$ & 66.5 & $(0.4)$ & 386 & (6) & 17598 (5748) & 11.8 & $(0.2)$ & 8.26 & $(0.01)$ \\
\hline Solid fraction mixed & 16.72 & $(0.13)$ & 870 & (7) & 2.39 & $(0.5)$ & 21.4 & $(1.0)$ & 511 & (8) & $2428(443)$ & 6.0 & $(0.5)$ & 8.88 & $(0.05)$ \\
\hline Solid fraction unmixed & 17.02 & $(0.37)$ & 872 & $(15)$ & 2.47 & $(0.1)$ & 23.1 & $(1.3)$ & 506 & (9) & $2226(758)$ & 5.2 & $(0.5)$ & 8.89 & $(0.06)$ \\
\hline End & & & & & & & & & & & & & & & \\
\hline Unseparated mixed & 5.65 & $(0.10)$ & 719 & $(12)$ & 34.7 & $(0.0)$ & 60.9 & $(1.8)$ & 462 & (12) & $11062(124)$ & 10.8 & $(0.5)$ & 7.96 & $(0.01)$ \\
\hline Unseparated unmixed & 5.84 & $(0.10)$ & 719 & (10) & 33.9 & $(0.7)$ & 57.9 & (1.9) & 402 & (5) & $8220(1267)$ & 9.9 & $(0.1)$ & 7.89 & $(0.05)$ \\
\hline Liquid fraction mixed & 4.50 & $(0.02)$ & 676 & $(15)$ & 41.1 & $(1.1)$ & 66.7 & $(0.4)$ & 424 & (2) & $18356(2156)$ & 13.7 & $(0.7)$ & 8.08 & $(0.02)$ \\
\hline Liquid fraction unmixed & 4.63 & $(0.21)$ & 667 & (30) & 41.9 & $(0.2)$ & 72.1 & (1.5) & 423 & (24) & $22873(324)$ & 12.7 & $(0.2)$ & 8.03 & $(0.01)$ \\
\hline Solid fraction mixed & 15.01 & $(0.25)$ & 864 & (14) & 2.1 & $(0.5)$ & 16.5 & $(0.1)$ & 543 & (5) & $3718(300)$ & 6.9 & $(0.5)$ & 8.89 & $(0.05)$ \\
\hline Solid fraction unmixed & 18.66 & $(0.33)$ & 863 & $(21)$ & 2.2 & $(0.2)$ & 20.1 & (2.0) & 418 & (67) & $2819(54)$ & 4.9 & $(0.2)$ & 8.77 & $(0.03)$ \\
\hline & & & & & & & nmer & & & & & & & & \\
\hline Start & & & & & & & & & & & & & & & \\
\hline Unseparated mixed & 6.30 & $(0.04)$ & 721 & (3) & 34.0 & $(1.1)$ & 62.0 & $(0.2)$ & 389 & (2) & $12190(111)$ & 10.6 & $(0.2)$ & 8.47 & $(0.04)$ \\
\hline Unseparated unmixed & 6.33 & $(0.05)$ & 717 & (3) & 33.8 & (1.3) & 60.9 & $(0.2)$ & 430 & (9) & $12227(190)$ & 11.5 & $(0.3)$ & 8.47 & $(0.08)$ \\
\hline Liquid fraction mixed & 5.01 & $(0.13)$ & 663 & $(12)$ & 42.7 & $(0.2)$ & 73.3 & $(0.6)$ & 388 & (4) & 19461 (1218) & 13.2 & $(0.4)$ & 8.52 & $(0.04)$ \\
\hline Liquid fraction unmixed & 5.21 & $(0.53)$ & 670 & (67) & 39.9 & $(7.1)$ & 70.7 & $(1.1)$ & 350 & (10) & $17543(749)$ & 13.1 & $(0.4)$ & 8.42 & $(0.03)$ \\
\hline Solid fraction mixed & 16.19 & $(0.04)$ & 850 & (7) & 8.2 & $(1.2)$ & 26.3 & $(0.4)$ & 409 & (1) & $988(25)$ & 5.6 & $(0.4)$ & 9.11 & $(0.01)$ \\
\hline Solid fraction unmixed & 15.82 & $(0.01)$ & 828 & (24) & 10.1 & (1.9) & 28.8 & $(0.1)$ & 419 & (4) & $1024(1144)$ & 5.7 & $(0.7)$ & 9.10 & $(0.01)$ \\
\hline End & & & & & & & & & & & & & & & \\
\hline Unseparated mixed & 5.57 & $(0.06)$ & 686 & (5) & 26.3 & $(1.1)$ & 41.9 & $(0.4)$ & 371 & (2) & 9192 (1329) & 11.8 & $(0.4)$ & 7.72 & $(0.03)$ \\
\hline Unseparated unmixed & 5.33 & $(0.31)$ & 681 & (49) & 28.9 & $(1.5)$ & 45.8 & $(0.2)$ & 398 & (4) & 10976 (1595) & 14.1 & $(0.4)$ & 7.65 & $(0.02)$ \\
\hline Liquid fraction mixed & 4.57 & $(0.28)$ & 606 & (20) & 26.9 & (2.8) & 46.7 & $(1.8)$ & 351 & (7) & 8928 (87) & 14.0 & $(0.4)$ & 7.85 & $(0.01)$ \\
\hline Liquid fraction unmixed & 4.03 & $(0.16)$ & 618 & $(15)$ & 32.5 & $(1.5)$ & 56.3 & $(0.3)$ & 354 & (5) & $14268(273)$ & 16.6 & $(0.7)$ & 7.75 & $(0.04)$ \\
\hline Solid fraction mixed & 10.76 & $(0.10)$ & 828 & (19) & 6.6 & $(0.0)$ & 30.7 & $(0.3)$ & 480 & (7) & 911 (37) & 8.6 & $(0.6)$ & 8.15 & $(0.04)$ \\
\hline Solid fraction unmixed & 10.92 & $(0.06)$ & 811 & (6) & 7.3 & $(0.9)$ & 26.1 & $(0.3)$ & 472 & (1) & $989(55)$ & 8.3 & $(1.0)$ & 8.07 & $(0.04)$ \\
\hline
\end{tabular}

†TS, total solids; VS, volatile solids; TAN, total ammoniacal nitrogen; TKN, total Kjeldahl nitrogen; TOC, total organic carbon; VFA, volatile fatty acid.

mathematically combined separated fractions, particularly from the liquid fraction because this fraction was characterized by a low solids content and high TAN concentration (Table 1), which facilitate $\mathrm{NH}_{3}$ volatilization (Arogo et al., 1999; Vaddella et al., 2013).

The changes in VFA were similar in both storage periods (Fig. 2). During the first weeks of each storage period, VFA production due to microbiological degradation was faster than VFA losses due to degradation (Møller et al., 2004). As observed by Popovic and Jensen (2012), the greatest losses of VFA occurred after the fourth week of storage. Temperature affects microbial activity and consequently VFA production; higher temperature in particular stimulates microbial activity and thus VFA production (Møller et al., 2004). Temperature also might affect VFA by affecting aerobic or methanogenic bacteria degradation intensity, which is higher at higher temperatures (Massé et al., 2008; Popovic and Jensen, 2012). This hypothesis can be partly confirmed by the observed $\mathrm{pH}$ trends (data not shown). In each storage period, $\mathrm{pH}$ decreased during the first month of storage, after which it tended to increase (except for solid fraction samples during summer storage). In similar studies, an initial $\mathrm{pH}$ reduction was also reported (Møller et al., 2004; Moset et al., 2012;
Patni and Jui, 1991) and was attributed to the rapid degradation of organic matter just after storage tanks are first filled, which causes VFA concentrations to increase, thus reducing $\mathrm{pH}$. Thereafter, oxidation of VFA may cause the $\mathrm{pH}$ to increase as some of the acids are removed (Paul and Beauchamp, 1989). After the first month of each storage period, $\mathrm{pH}$ variations were limited. The average $\mathrm{pH}$ of mixed liquid fraction, mixed solid fraction, and mixed unseparated digestate were 7.99, 8.55 , and 7.85, respectively, during winter storage, and 7.75 , 8.36, and 7.70, respectively, during summer storage (Table 1). The somewhat lower $\mathrm{pH}$ observed during summer storage may be explained by the higher $\mathrm{C}$ and $\mathrm{N}$ losses that occurred compared with winter storage losses, both of which could affect $\mathrm{pH}$ (Sommer et al., 2006).

Total inorganic carbon $\left(\mathrm{TIC}=\mathrm{CO}_{2}+\mathrm{HCO}_{3}^{-}+\mathrm{CO}_{3}{ }^{2-}\right)$, total ammoniacal nitrogen ( $\left.\mathrm{TAN}=\mathrm{NH}_{3}+\mathrm{NH}_{4}^{+}\right)$, and total acetic acid $\left(\mathrm{TAc}=\left[\mathrm{CH}_{3} \mathrm{COOH}\right]+\left[\mathrm{CH}_{3} \mathrm{COO}^{-}\right]\right)$are the main buffer components controlling the $\mathrm{pH}$ in manure (Blanes-Vidal et al., 2009). In particular, losses of $\mathrm{NH}_{3}$ (which is an alkaline gas) tend to reduce $\mathrm{pH}$, which adds to the aforementioned VFA production effect (Blanes-Vidal et al., 2012; Sommer et al., 
WINTER STORAGE

-- -COMB_M $\multimap-$ UNSEP_M
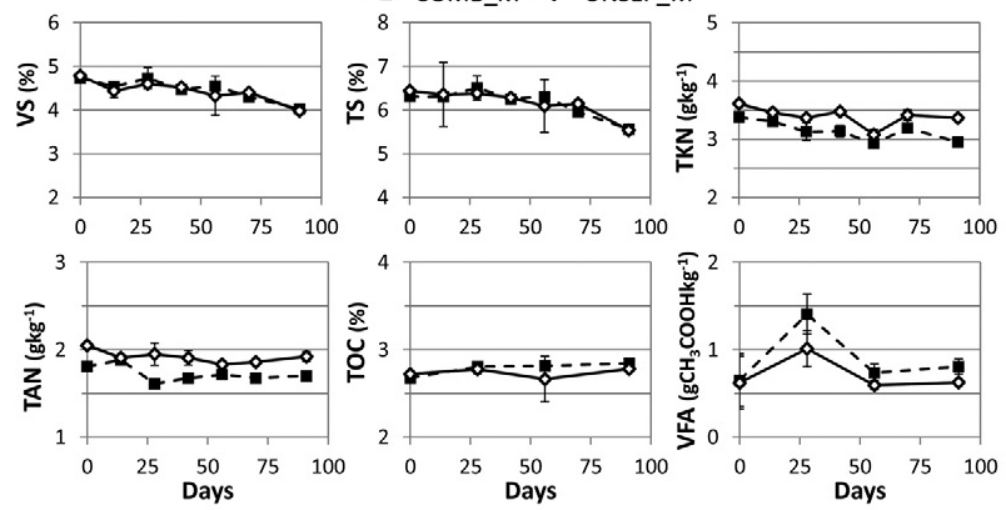

SUMMER STORAGE
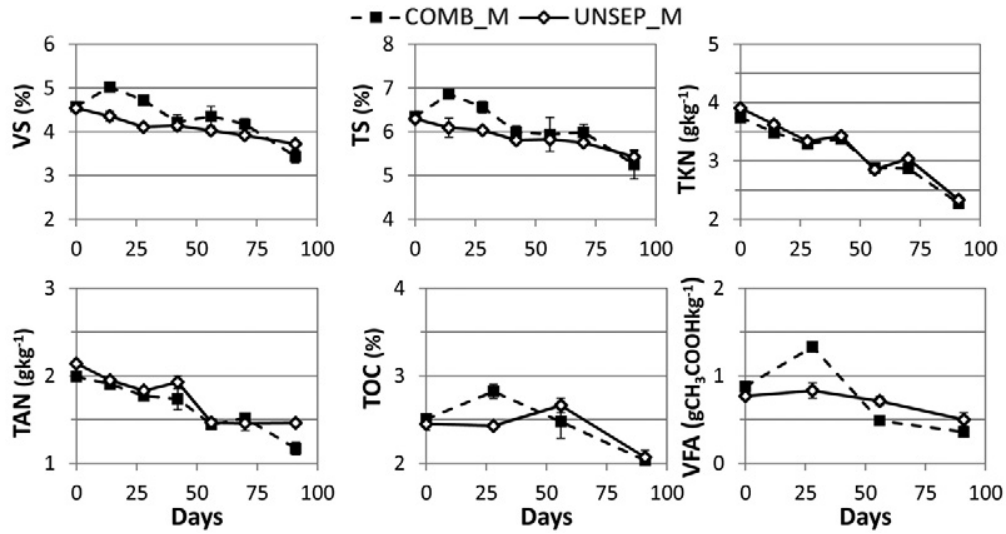

Fig. 2. Chemical parameters of materials during winter and summer storage periods. Data are expressed on a fresh weight basis and are averages of results from duplicate containers for each material type. Error bars represent \pm SD. Material types were unseparated mixed digestate (UNSEP_M) and mathematically combined separated fractions that were mixed (COMB_M). TAN, total ammoniacal nitrogen; TKN, total Kjeldahl nitrogen; TOC, total organic carbon; TS, total solids; VFA, volatile fatty acids; VS, volatile solids.

2006). In contrast, $\mathrm{CO}_{2}$ (which is an acidic gas), together with VFA oxidation, increases $\mathrm{pH}$ (Blanes-Vidal et al., 2009, 2012).

\section{Effects on Mass Losses}

Figure 3 presents the TKN and TOC losses observed during the two storage periods. The TOC losses were significantly $(P=0.006)$ affected by season but not by mechanical separation $(P=0.80)$ or mixing $(P=0.78)$ (Table 3$)$. During winter storage, TOC losses were very limited (on average $3.5 \%$ of TOC) with no significant differences $(P>0.05)$ between treatments (mixing and mechanical separation). Losses of TOC during summer storage ranged between 13 and $23 \%$ of the initial TOC for unseparated digestate that was mixed and unmixed, respectively, while the combined losses from the separated fractions that were mixed and unmixed were between 17 and 20\%, respectively. Losses of TKN were significantly affected by season $(P<0.001)$, by the interactions between mechanical separation and mixing $(P=0.01)$, and by interactions between season, mixing, and mechanical separation $(P=0.01)$. Moreover, TKN losses tended to be affected by mixing, although this was not statistically significant $(P<0.10)$.

In the winter storage period, $\mathrm{N}$ losses were limited. The losses of $\mathrm{N}$ as a percentage of initial TKN from unseparated digestate that was mixed and unmixed were 4.9 and $7.7 \%$, respectively (Fig. 3). Similarly, the combined $\mathrm{N}$ losses from the separated fractions that were mixed and unmixed were 12.6 and $2.2 \%$, respectively. These results are in line with those of Patni and Jui (1991) who observed that in winter, $\mathrm{N}$ losses were between 4.4 and $8.4 \%$ from two stores filled with dairy slurry and left undisturbed for the entire storage period. In the present study during winter storage, the highest $\mathrm{N}$ loss (considering the mass unit for each material) was observed from the mixed solid fraction, which is in line with the results of Chadwick (2005), who found losses of 27 to $35 \%$ of total $\mathrm{N}$ from conventionally stored farmyard manure during the three winter months. Considering the combined losses from the separated fractions that were mixed and unmixed, the solid fraction contributed 26 and $40 \%$ of the total TKN loss, respectively. The higher contribution of the solid fraction in the unmixed treatment can be explained by the limited losses of the unmixed liquid fraction in the winter period (1.3\%) compared with those of the mixed liquid fraction (9.3\%). In the summer storage period, unseparated digestate and mathematically combined separated fractions lost, on average, $38 \%$ of their initial TKN (Fig. 3). Overall, both C and $\mathrm{N}$ losses from unseparated and separated digestate were similar, possibly related to the atmospheric conditions (i.e., excessive rainfall in winter, drying in summer) that influenced the state of the surface layer (Blanes-Vidal et al., 2009). In particular, the presence of a crust in summer and a very dilute liquid layer in winter may have affected both separated and unseparated digestate in the same way by providing something of a buffer between the atmosphere and the bulk samples

Table 2. Effect of mechanical separation and time of sampling on total solids (TS), volatile solids (VS), total organic carbon (TOC), total ammoniacal nitrogen (TAN), total Kjeldahl nitrogen (TKN), and volatile fatty acids (VFA) contents during winter storage and summer storage ( $P$ values).

\begin{tabular}{|c|c|c|c|c|c|c|}
\hline & \multicolumn{6}{|c|}{$P$ values } \\
\hline & TS & VS & TOC & TAN & TKN & VFA \\
\hline \multicolumn{7}{|c|}{ Winter storage } \\
\hline Mechanical separation & 0.125 & 0.652 & 0.329 & $<0.001$ & $<0.001$ & 0.090 \\
\hline Time of sampling & 0.027 & 0.002 & 0.388 & 0.015 & $<0.001$ & 0.009 \\
\hline Mechanical separation $\times$ time of sampling & 0.057 & 0.706 & 0.565 & 0.082 & 0.124 & 0.616 \\
\hline \multicolumn{7}{|c|}{ Summer storage } \\
\hline Mechanical separation & 0.004 & 0.001 & 0.273 & $<0.001$ & $<0.001$ & 0.050 \\
\hline Time of sampling & $<0.001$ & $<0.001$ & $<0.001$ & $<0.001$ & $<0.001$ & $<0.001$ \\
\hline Mechanical separation $\times$ time of sampling & 0.044 & 0.001 & 0.016 & 0.006 & 0.008 & $<0.001$ \\
\hline
\end{tabular}



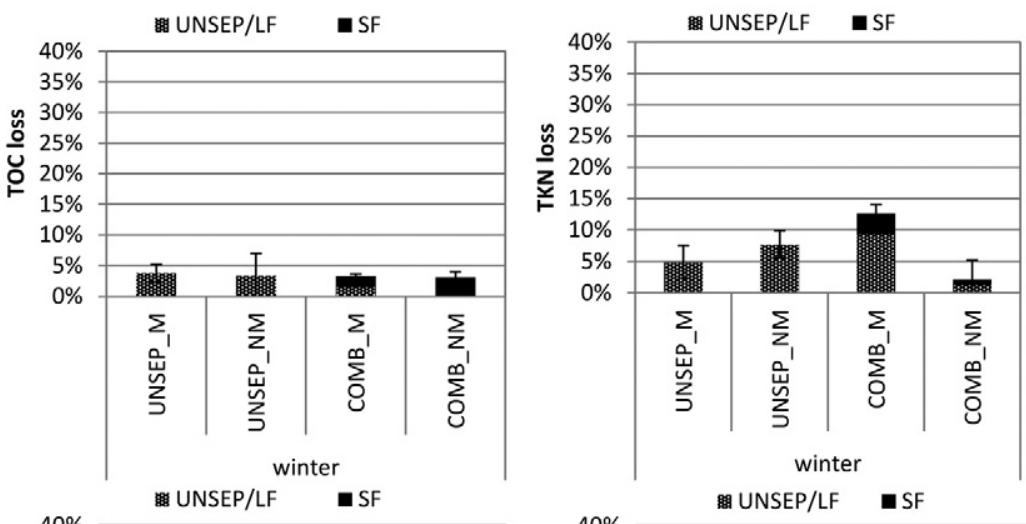

TKN than unmixed ones (Fig. 3). This result may be due to the aforesaid physical condition of the surface layer of samples. During winter storage, a very dilute and wet layer, as observed during the sampling days, formed on the surface of all materials, including the solid fraction. This layer probably further inhibited gaseous emissions that were already retarded by the low temperatures (Sommer et al., 2013, Cardenas et al., 2016). Thus, mixing tended to increase the surface area of material exposed to the atmosphere and caused a substantial increase in TKN losses, especially from solid-fraction containers. Furthermore,
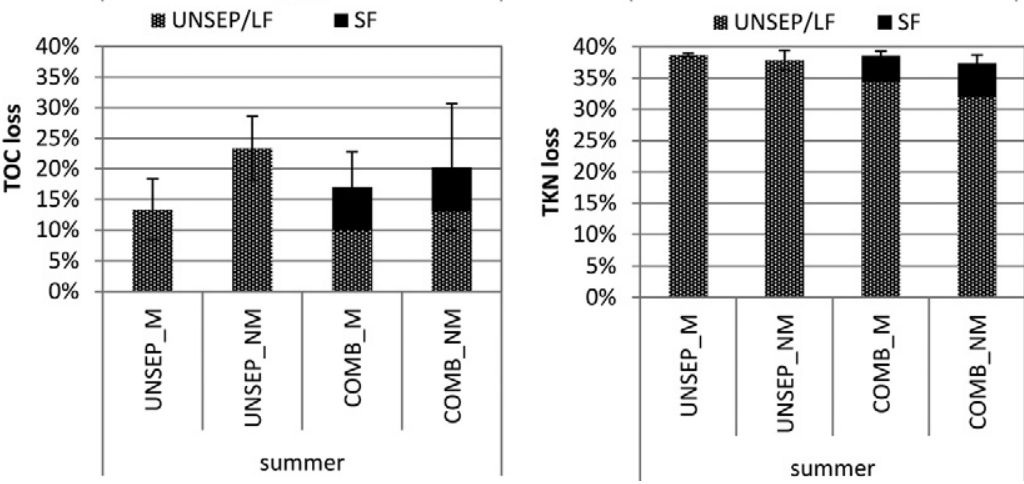

Fig. 3. Total Kjeldahl nitrogen (TKN) and total organic carbon (TOC) losses during winter storage and summer storage, expressed as percentage of initial TKN and TOC, respectively. Error bars represent \pm standard deviation. Sample types were anaerobically digested cattle slurry that was mixed (UNSEP_M) and unmixed (UNSEP_NM). Mathematically combined losses from liquid (LF) and solid fractions (SF) that were mixed (COMB_M) and unmixed (COMB_NM) are shown for comparison to UNSEP_M and UNSEP_NM, respectively.

(Misselbrook et al., 2005). Thus, slurry composition was not the main factor that determined the emissions.

Mixing generally did not cause changes in TOC and TKN losses (Table 3). Compared with the losses observed in the present study, VanderZaag et al. (2010b) measured TKN and TOC losses that were approximately 20\% lower and $15 \%$ higher, respectively, during a 5-mo storage of dairy slurry in Canada. The differences between findings of the current study and that of VanderZaag et al. (2010b) could be related (i) to the lower temperatures in Canada (where the average temperature between May and September was $15-20^{\circ} \mathrm{C}$ ) than in Italy, which influenced the state of the surface layer, and (ii) to the longer storage period $(5 \mathrm{mo})$ than that used in the present study $(3 \mathrm{mo})$. Marked differences in TKN losses were observed during winter storage only, when mathematically combined mixed separated fractions lost six times more

Table 3. Effect of season, mechanical separation, and mixing on total Kjeldahl nitrogen (TKN) and total organic carbon (TOC) losses during storage ( $P$ values).

\begin{tabular}{lcc}
\hline & \multicolumn{2}{c}{$P$ values } \\
\cline { 2 - 3 } & TKN loss & TOC loss \\
\hline Season & $<0.001$ & 0.006 \\
Mechanical separation & 0.981 & 0.801 \\
Mixing & 0.056 & 0.783 \\
Season $\times$ mechanical separation & 0.498 & 0.797 \\
Season $\times$ mixing & 0.114 & 0.945 \\
Mechanical separation $\times$ mixing & 0.013 & 0.469 \\
Season $\times$ mechanical separation $\times$ mixing & 0.008 & 0.580 \\
\hline
\end{tabular}

we observed that in winter the effect of mixing was more protracted in time; no crust formation was observed during any of the sampling days. In contrast, in summer crust tended to reform very quickly after mixing, explaining why differences in $\mathrm{N}$ emission were only detectable by observing fluxes (see next section, "Gas Flux Measurements and Some Considerations on the Manure Management Continuum"), which were measured immediately after mixing. Most likely, mixed materials, after the crust reformed, had similar gaseous emissions as unmixed ones. The liquid fraction (mixed and unmixed), on average during summer storage, was responsible for 85 to $90 \%$ of total $\mathrm{N}$ losses and 58 to $64 \%$ of total C losses from separated digestate (weighted separated fractions that were mixed and unmixed) (Fig. 3).

\section{Gas Flux Measurements and Some Considerations on the Manure Management Continuum}

The measured fluxes identified the most probable forms of $\mathrm{N}$ and $\mathrm{C}$ losses. Table 4 shows the means of measured fluxes and the $P$ values of the effects of season, mixing, and mechanical separation. The mixing effect is reported separately for the effect of season, and within season for the effect of mechanical separation. Similarly, the mechanical separation effect is reported separately for the effect of the season, and within season for the effect of mixing. The measured fluxes showed that $\mathrm{N}$ losses from unseparated digestate and from the mathematically combined separated fractions occurred almost entirely as $\mathrm{NH}_{3}$ (95-99.5\%); thus, $\mathrm{N}$ losses probably occurred in this form during the entire period of storage. The measured $\mathrm{C}$ fluxes $\left(\mathrm{CO}_{2}+\mathrm{CH}_{4}\right)$ showed that $\mathrm{CO}_{2}$ (on average $65-98 \%$ of TOC loss) was the main form of $\mathrm{C}$ loss. Furthermore, the observed fluxes expressed in terms of $\mathrm{CO}_{2 \mathrm{eq}}$ (which comprised $\mathrm{N}_{2} \mathrm{O}$ and $\mathrm{CH}_{4}$ emissions) indicated that $\mathrm{CH}_{4}$ represented 25 to $40 \%$ of emissions in winter and 70 to $80 \%$ in summer. The effect of seasons was statistically significant for all gaseous emissions (expressed as $\mathrm{g} \mathrm{t}^{-1} \mathrm{~d}^{-1}$ ) considered, but $\mathrm{NH}_{3}$ and $\mathrm{CH}_{4}$ were especially influenced by temperature (Table 4 ). Mechanical separation (unseparated digestate vs. mathematically combined separated fractions) caused significant differences in GHG emissions, expressed in terms of $\mathrm{CO}_{2 \mathrm{eq}}$ (Table 4). During winter storage, $\mathrm{CO}_{2 \mathrm{eq}}$ emissions were higher $(P<0.05)$ from mathematically combined unmixed separated fractions 
Table 4. Mean $\mathrm{NH}_{3}, \mathrm{~N}_{2} \mathrm{O}, \mathrm{CH}_{4}, \mathrm{CO}_{2^{\prime}}$, and $\mathrm{CO}_{2 \text { eq }}$ (carbon dioxide equivalent of $\mathrm{CH}_{4}$ and $\mathrm{N}_{2} \mathrm{O}$ ) fluxes expressed on a daily and weight (tonne) basis during winter storage and summer storage. Standard deviations are given in parentheses. Data are shown for the liquid and solid fractions of mechanically separated digestate, unseparated digestate, and the mathematically combined separated fractions. $P$ values are also shown concerning the effect of season, mechanical separation, and mixing during winter storage and summer storage on $\mathrm{NH}_{3^{\prime}}, \mathrm{N}_{2} \mathrm{O}, \mathrm{CH}_{4^{\prime}} \mathrm{CO}_{2^{\prime}}$ and $\mathrm{CO}_{2 \mathrm{eq}}$ emissions.

\begin{tabular}{|c|c|c|c|c|c|}
\hline & $\mathrm{N}-\mathrm{NH}_{3}$ & $\mathrm{~N}_{2} \mathrm{O}$ & $\mathrm{CH}_{4}$ & $\mathrm{CO}_{2}$ & $\mathrm{CH}_{4}+\mathrm{N}_{2} \mathrm{O}$ \\
\hline & & + & & & $\mathrm{CO}_{2 \mathrm{eq}}$ \\
\hline & & Winter stor & & & \\
\hline \multicolumn{6}{|l|}{ Mixed } \\
\hline Liquid fraction & $0.24(0.01)$ & $0.01(0.00)$ & $0.08(0.06)$ & $4.9(1.2)$ & $4.5(2.3)$ \\
\hline Solid fraction & $0.06(0.02)$ & $0.22(0.07)$ & $0.43(0.14)$ & $29.8(9.4)$ & $76.1(23.6)$ \\
\hline Combined separated fractions & $0.22(0.01)$ & $0.03(0.01)$ & $0.12(0.06)$ & $9.7(1.7)$ & $10.9(4.2)$ \\
\hline Unseparated & $0.27(0.03)$ & $0.01(0.00)$ & $0.05(0.02)$ & $8.1(2.7)$ & $4.7(0.89)$ \\
\hline \multicolumn{6}{|l|}{ Unmixed } \\
\hline Liquid fraction & $0.10(0.00)$ & $0.01(0.00)$ & $0.09(0.01)$ & $10.3(1.8)$ & $6.2(0.6)$ \\
\hline Solid fraction & $0.04(0.02)$ & $0.21(0.06)$ & $0.43(0.01)$ & $32.3(2.9)$ & $74.2(18.2)$ \\
\hline Combined separated fractions & $0.10(0.01)$ & $0.03(0.00)$ & $0.12(0.01)$ & $13.8(0.4)$ & $12.3(1.1)$ \\
\hline Unseparated & $0.12(0.00)$ & $0.01(0.00)$ & $0.08(0.00)$ & $12.5(2.1)$ & $6.2(0.2)$ \\
\hline \multicolumn{6}{|c|}{ Summer storage } \\
\hline \multicolumn{6}{|l|}{ Mixed } \\
\hline Liquid fraction & $1.67(0.03)$ & $0.01(0.00)$ & $1.61(0.10)$ & $19.6(0.5)$ & $43.2(1.9)$ \\
\hline Solid fraction & $3.29(0.80)$ & $0.35(0.02)$ & $0.46(0.26)$ & $119.7(6.1)$ & $140.0(2.2)$ \\
\hline Combined separated fractions & $1.86(0.12)$ & $0.05(0.37)$ & $1.47(0.06)$ & $31.6(1.2)$ & $52.1(1.9)$ \\
\hline Unseparated & $2.14(0.11)$ & $0.02(0.01)$ & $2.45(1.16)$ & $21.0(3.4)$ & $64.2(31.1)$ \\
\hline \multicolumn{6}{|l|}{ Unmixed } \\
\hline Liquid fraction & $1.07(0.02)$ & $0.00(0.35)$ & $2.03(0.11)$ & $14.8(0.5)$ & $52.2(3.0)$ \\
\hline Solid fraction & $3.80(3.60)$ & $0.43(0.19)$ & $0.55(0.03)$ & $90.3(4.7)$ & $156.3(45.2)$ \\
\hline Combined separated fractions & $1.40(0.50)$ & $0.055(0.01)$ & $1.85(0.1)$ & $23.9(0.1)$ & $62.9(9.6)$ \\
\hline Unseparated & $1.08(0.17)$ & $0.050(0.02)$ & $3.27(0.71)$ & $18.4(1.2)$ & $97.4(23.2)$ \\
\hline \multicolumn{6}{|c|}{$P$ values } \\
\hline Season & $<0.0001$ & 0.027 & $<0.0001$ & $<0.0001$ & $<0.0001$ \\
\hline \multicolumn{6}{|l|}{ Mixing } \\
\hline \multicolumn{6}{|l|}{ Winter } \\
\hline Combined separated fractions & 0.001 & 0.78 & 0.96 & 0.10 & 0.80 \\
\hline Unseparated & 0.007 & 0.62 & 0.31 & 0.29 & 0.29 \\
\hline \multicolumn{6}{|l|}{ Summer } \\
\hline Combined separated fractions & 0.078 & 0.766 & 0.012 & 0.004 & 0.028 \\
\hline Unseparated & $<0.0001$ & 0.042 & 0.065 & 0.13 & 0.004 \\
\hline \multicolumn{6}{|l|}{ Separation } \\
\hline \multicolumn{6}{|l|}{ Winter } \\
\hline Mixed & 0.037 & 0.16 & 0.50 & 0.24 & 0.14 \\
\hline Unmixed & 0.18 & 0.044 & 0.094 & 0.25 & 0.016 \\
\hline \multicolumn{6}{|l|}{ Summer } \\
\hline Mixed & 0.36 & 0.62 & 0.002 & $<0.0001$ & 0.005 \\
\hline Unmixed & 0.38 & 0.12 & 0.32 & 0.45 & 0.64 \\
\hline
\end{tabular}

and consisted mainly of $\mathrm{CH}_{4}$ and $\mathrm{N}_{2} \mathrm{O}$ emissions from the solid fraction (57\%) (Table 4). In contrast, during summer storage, generally lower $\mathrm{CH}_{4}$ and $\mathrm{CO}_{2 \mathrm{eq}}$ emissions $(P<0.01$ for mixed materials) were observed from the combined separated fractions; this was mainly due to the comparatively lower $\mathrm{CH}_{4}$ production from the liquid fraction, which was characterized by a low availability of solids (Wood et al., 2012). Of the two fractions, solid and liquid, the liquid fraction was the greater contributor $(75 \%)$ to $\mathrm{CO}_{2 \mathrm{eq}}$ emissions from separated digestate. Mechanical separation also caused higher $\mathrm{CO}_{2}$ emission during summer storage, probably due to the production of a solid fraction that was rich in readily available $C$ (Dinuccio et al., 2008). Mixing, except for separated fractions during summer storage, always caused a significant $(P<0.01)$ increase in $\mathrm{NH}_{3}$ emissions. Lower $\mathrm{CH}_{4}$ emissions after mixing were found during summer storage from both unseparated digestate and separated digestate. Mixing probably altered the anaerobic conditions that had developed in the materials and thus altered the activity of methanogenic bacteria (Perazzolo et al., 2015). In other studies, mild agitation of slurry increased $\mathrm{CH}_{4}$ emissions by releasing dissolved gas and bubbles (Park et al., 2010; VanderZaag et al., 2010a).

The results of the present study indicate that mechanical separation did not cause significant differences in $\mathrm{N}$ and $\mathrm{C}$ losses during storage, although lower GHG emissions during storage of the fractions from separated digestate occurred due to the lower $\mathrm{CH}_{4}$ emissions from the liquid fraction.

Furthermore, it is important to note that because the materials investigated were digested, a greater reduction in $\mathrm{CH}_{4}$ 
emission can be expected from the storage of these materials than from the storage of raw slurries. Although this comparison was not performed in the present research, several previous studies (Amon et al., 2006; Clemens et al., 2006) demonstrated that anaerobic digestion may cause a reduction of $\mathrm{CH}_{4}$ production during storage (up to $65 \%$ ), having the potential to mitigate GHG emission. Additional benefits from mechanical separation can be expected during land spreading, especially reduced $\mathrm{NH}_{3}$ losses after liquid fraction spreading (Amon et al., 2006; Monaco et al., 2012). In Europe, most (up to 90\%) $\mathrm{NH}_{3}$ losses during manure management (storage plus application) occur during land spreading (Sommer and Hutchings, 2001). Other studies have shown that mechanical separation may reduce $\mathrm{NH}_{3}$ emission (by up to $60 \%$ ) due to better infiltration of liquid fraction into soil (Amon et al., 2006; Monaco et al., 2012). Dry matter content has been shown to significantly affect $\mathrm{NH}_{3}$ emissions, such that $\mathrm{NH}_{3}$ emissions increase concurrently with an increase in slurry dry matter content (Sommer and Hutchings, 2001). Furthermore, the benefits derived from liquid fraction spreading can be increased by using application techniques that ensure low $\mathrm{NH}_{3}$ emissions. In particular, for this purpose, incorporation into soil by plowing or harrowing immediately after surface application and direct injection into soil were shown to be very effective $\mathrm{NH}_{3}$ control methods, with reductions in $\mathrm{NH}_{3}$ losses of up to 70 to $80 \%$ (Sommer et al., 2013; Webb et al., 2012).

\section{Conclusions}

This study provides useful information concerning $\mathrm{C}$ and $\mathrm{N}$ losses from digested cattle slurry in pilot-scale storage conditions. The $\mathrm{N}$ and $\mathrm{C}$ losses occurred primarily as $\mathrm{NH}_{3}(95-$ 99\%) and $\mathrm{CO}_{2}$ (65-98\%). Mechanical separation did not significantly affect the magnitudes of $\mathrm{C}$ and $\mathrm{N}$ losses; however, it did reduce $\mathrm{C}$ lost in the form of $\mathrm{CH}_{4}$. Mixing tended to significantly increase $\mathrm{N}$ losses (by as much as six times), but only in winter. Our results indicate that mixing operations should be limited to avoid increasing $\mathrm{NH}_{3}$ emissions because season and climatic conditions significantly affect $\mathrm{N}$ and $\mathrm{C}$ losses. Dairy producers should adopt mitigation techniques to prevent $\mathrm{C}$ and $\mathrm{N}$ losses and preserve the fertilizer quality of their manures, especially during warm temperatures when the major portion (up to 23 and $38 \%$ of initial TOC and TKN, respectively) of emissions occurs. During summer storage of separated digestate, most of the $\mathrm{N}$ and $\mathrm{C}$ losses (up to 85\% and $64 \%$, respectively) occur from the liquid fraction; thus, mitigation strategies should be focused on the storage of this fraction. The effective reduction of $\mathrm{C}$ and $\mathrm{N}$ losses may be obtained only with strategies that consider all the management operations.

\section{Acknowledgments}

This study was carried out under the project "Definition of best practices at low emissions for the management and agronomic utilization of manure (NER0)" granted by the Lombardy Regional Government and the project "Multi-regional solution to improve the environmental and economic sustainability of pig manure management in the Regional of the Po and Veneto basin," supported by Progetto AGER, grant no. 2010-2220. We thank the staff of the Azienda Mezozzi, Landriano (PV), and Azienda Rinaldi, Lodi Vecchio, for their kind support.

\section{References}

Amon, B., T. Kryvoruchko, V. Amon, and S. Zechmeister-Boltenstern. 2006. Methane, nitrous oxide, and ammonia emissions during storage and after application of dairy cattle slurry and influence of slurry treatment. Agric. Ecosyst. Environ. 112:153-162. doi:10.1016/j.agee.2005.08.030

Amon, B., V. Kryvoruchko, M. Frohlich, T. Amon, A. Pollinger, I. Mosenbacher, and A. Hausleitner. 2007. Ammonia and greenhouse emission from a straw flow system for fattening pigs: Housing and manure storage. Livest. Sci. 112:199-207. doi:10.1016/j.livsci.2007.09.003

APHA, AWWA, and WEF. 2012. Standard methods for the examination of water and wastewater. 21st ed. American Public Health Association, Washington, DC.

Arogo, J., R.H. Zhang, G.L. Riskowski, L.L. Christianson, and D.L. Day. 1999. Mass transfer coefficient of ammonia on liquid swine manure and aqueous solutions. J. Agric. Eng. Res. 73:77-86. doi:10.1006/jaer.1998.0390

ARPA. 2015. Daily data of the weather station located in Landriano (temperature and rainfall) for years 2005-2014. Regional Agency for Environmental Protection of Lombardia. http://www.arpalombardia.it (accessed May 2015).

Balsari, P., G. Airoldi, E. Dinuccio, and F. Gioelli. 2007. Ammonia emissions from farmyard manure heaps and slurry stores- effect of environmental conditions and measuring methods. Biosystems Eng. 97(4):456-463. doi:10.1016/j.biosystemseng.2007.03.033

Blanes-Vidal, V., M. Guàrdia, X.R. Dai, and E.S. Nadimi. 2012. Emissions of $\mathrm{NH}_{3}, \mathrm{CO}_{2}$ and $\mathrm{H}_{2} \mathrm{~S}$ during swine wastewater management: Characterization of transient emissions after air-liquid interface disturbances. Atmos. Environ. 54:408-418. doi:10.1016/j.atmosenv.2012.02.046

Blanes-Vidal, V., S.G. Sommer, and E.S. Nadimi. 2009. Modelling surface $\mathrm{pH}$ and emissions of hydrogen sulphide, ammonia, acetic acid, and carbon dioxide from a pig waste lagoon. Biosystems Eng. 104:510-521. doi:10.1016/j. biosystemseng.2009.09.008

Burton, C.H., and C. Turner. 2003. Manure management: Treatment strategies for sustainable agriculture. Silsoe Research Institute, Bedford, UK.

Cardenas, L.M., T. Misselbrook, C. Hodgson, N. Donovan, S. Gilhespy, K.A. Smith, M.S. Dhanoa, and D. Chadwick. 2016. Effect of the application of cattle urine with or without the nitrification inhibitor DCD, and dung on greenhouse gas emissions from a UK grassland soil. Agric. Ecosyst. Environ. 235:229-241. doi:10.1016/j.agee.2016.10.025

Chadwick, D. 2005. Emissions of ammonia, nitrous oxide and methane form cattle manure heaps: Effect of compaction and covering. Atmos. Environ. 39:787-799. doi:10.1016/j.atmosenv.2004.10.012

Chadwick, D., S. Sommer, R. Thorman, D. Fangueiro, L. Cardenas, B. Amon, and T. Misselbrook. 2011. Manure management: Implication for greenhouse gas emissions. Anim. Feed Sci. Technol. 166-167:514-531. doi:10.1016/j. anifeedsci.2011.04.036

Clemens, J., M. Trimborn, P. Weiland, and B. Amon. 2006. Mitigation of greenhouse gas emissions by anaerobic digestion of cattle slurry. Agric. Ecosyst. Environ. 112:171-177. doi:10.1016/j.agee.2005.08.016

Cocolo, G., M. Hjorth, A. Zarebska, and G. Provolo. 2016. Effect of acidification on solid-liquid separation of pig slurry. Biosystems Eng. 143:20-27. doi:10.1016/j.biosystemseng.2015.11.004

Dinuccio, E., W. Berg, and P. Balsari. 2008. Gaseous emissions from the storage of untreated slurries and fractions obtained after mechanical separation. Atmos. Environ. 42:2448-2459. doi:10.1016/j.atmosenv.2007.12.022

Dinuccio, E., F. Gioelli, P. Balsari, and N. Dorno. 2012. Ammonia losses from the storage and application of raw and chemo-mechanically separated slurry. Agric. Ecosyst. Environ. 153:16-23. doi:10.1016/j.agee.2012.02.015

Fangueiro, D., J. Coutinho, D. Chadwick, and N. Moreira. 2008. Effect of cattle slurry separation on greenhouse gas and ammonia emissions during storage. J. Environ. Qual. 37:2322-2331. doi:10.2134/jeq2007.0330

Hansen, M.N., K. Henriksen, and S.G. Sommer. 2006. Observations of production and emission of greenhouse gases and ammonia during storage of solids separated from pig slurry: Effects of covering. Atmos. Environ. 40:4172-4181. doi:10.1016/j.atmosenv.2006.02.013

Massé, D.I., L. Masse, S. Claveau, C. Benchaar, and O. Thomas. 2008. Methane emissions from manure storages. Trans. ASABE 51:1775-1781. doi: $10.13031 / 2013.25311$

Misselbrook, T., S.K.E. Brookman, K.A. Smith and T. Cumby. 2005. Crusting of stored dairy slurry to abate ammonia emissions: Pilot-scale studies. J. Environ. Qual. 34:411-419. doi:10.2134/jeq2005.0411dup

Misselbrook, T., J. Hunt, F. Perazzolo, and G. Provolo. 2016. Greenhouse gas and ammonia emissions from slurry storage: Impacts of temperature and potential mitigation through covering (pig slurry) or acidification (cattle slurry). J. Environ. Qual. 45:1520-1530. doi:10.2134/ jeq2015.12.0618 
Møller, H.B., S.G. Sommer, and K. Ahring. 2004. Biological degradation and greenhouse gas emissions during pre-storage of liquid animal manure. J. Environ. Qual. 33:27-36. doi:10.2134/jeq2004.2700

Monaco, S., D. Sacco, S. Pelissetti, E. Dinuccio, P. Balsari, M. Rostami, and C. Grignani. 2012. Laboratory assessment of ammonia emission after soil application of treated and untreated manures. J. Agric. Sci. 150:65-73. doi:10.1017/S0021859611000487

Moset, V., M. Cambra-Lopez, F. Estelles, A.G. Torres, and A. Cerisuelo. 2012. Evolution of chemical composition and gas emissions from aged pig slurry during outdoor storage with and without prior solid separation. Biosystems Eng. 111:2-10. doi:10.1016/j.biosystemseng.2011.10.001

Myhre, G., D. Shindell, F.M. Bréon, W. Collins, J. Fuglestvedt, J. Huang, D. Koch, J.-F. Lamarque, D. Lee, B. Mendoza, T. Nakajima, A. Robock, G. Stephens, T. Takemura, and H. Zhang. 2013. Anthropogenic and natural radiative forcing. In: T.F. Stocker, et al., editors, Climate change 2013: The physical science basis. Contribution of Working Group I to the Fifth Assessment Report of the Intergovernmental Panel on Climate Change. Cambridge Univ. Press, Cambridge, UK.

Oenema, O., D. Oudendag, and G.L. Velthof. 2007. Nutrient losses from manure management in the European Union. Livest. Sci. 112:261-272. doi:10.1016/j.livsci.2007.09.007

Park, K.H., C. Wagner-Riddle, and R.J. Gordon. 2010. Comparing methane fluxes from stored liquid manure using micrometeorological mass balance and floating chamber methods. Agric. For. Meteorol. 150:175-181. doi:10.1016/j.agrformet.2009.09.013

Patni, N.K., and P.Y. Jui. 1991. Nitrogen concentration variability in dairy-cattle slurry stored in farm tanks. Trans. ASAE 34:609-615. doi: $10.13031 / 2013.31707$

Paul, J.V., and E.G. Beauchamp. 1989. Relationship between volatile fatty acids, total ammonia, and $\mathrm{pH}$ in manure slurries. Biol. Wastes 29:313-318. doi:10.1016/0269-7483(89)90022-0

Perazzolo, F., G. Mattachini, F. Tambone, T. Misselbrook, and G. Provolo. 2015. Effect of mechanical separation on emission during storage of two anaerobically codigested animal slurries. Agric. Ecosyst. Environ. 207:1-9. doi:10.1016/j.agee.2015.03.023

Petersen, J., and P. Sorensen. 2008. Loss of nitrogen and carbon during storage of the fibrous fraction of separated pig slurry and influence on nitrogen availability. J. Agric. Sci. 146:403-413. doi:10.1017/S0021859607007654

Petersen, O.S., A.J. Andersen, and J. Eriksen. 2012. Effects of cattle slurry acidification on ammonia and methane evolution during storage. J. Environ. Qual. 41:88-94. doi:10.2134/jeq2011.0184

Popovic, O., and L.S. Jensen. 2012. Storage temperature affects distribution of carbon, VFA, ammonia, phosphorus, copper and zinc in raw pig slurry and its separated liquid fraction. Water Resour. 46:3849-3858.
SAS Institute. 2011. SAS system for Windows. v. 9.3. SAS Inst., Cary, NC.

Sommer, S.G., M.L. Christensen, T. Schmidt, and L.S. Jensen. 2013. Sanitation and hygiene in manure management. In: S.G. Sommer, et al., editors, Animal manure recycling: Treatment and management. John Wiley \& Sons, Chichester, UK. p. 91-104. doi:10.1002/9781118676677

Sommer, S.G., and N.J. Hutchings. 2001. Ammonia emission from field applied manure and its reduction. Eur. J. Agron. 15:1-15. doi:10.1016/ S1161-0301(01)00112-5

Sommer, S.G., G.Q. Zhang, A. Bennink, D. Chadwick, T. Misselbrook, R. Harrison, N.J. Hutchings, H. Menzi, G.J. Monteny, J.Q. Ni, O. Onema, and J. Webb. 2006. Algorithms determining ammonia emission from buildings housing cattle and pigs and from manure stores. Adv. Agron. 89:261-335. doi:10.1016/S0065-2113(05)89006-6

Tittonell, P., M.C. Rufino, B.H. Janssen, and K.E. Giller. 2010. Carbon and nutrient losses during manure storage under traditional and improved practices in smallholder crop-livestock systems: Evidence from Kenya. Plant Soil 328:253-269. doi:10.1007/s11104-009-0107-x

Tran, M.T., T.K.V. Vu, S.G. Sommer, and L.S. Jensen. 2011. Nitrogen turnover and loss during storage of slurry and composting of solid manure under typical Vietnamese farming conditions. J. Agric. Sci. 149:285-296. doi:10.1017/S0021859610000699

Vaddella, V.K., P.M. Ndegwa, J.L. Ullman, and A. Jiang. 2013. Mass transfer coefficients of ammonia for liquid dairy manure. Atmos. Environ. 66:107113. doi: 10.1016/j.atmosenv.2012.07.063

VanderZaag, A.C., R.J. Gordon, R.C. Jamieson, D.L. Burton, and G.W. Stratton. 2010a. Effects of winter storage conditions and subsequent agitation on gaseous emissions from liquid dairy manure. Can. J. Soil Sci. 90:229-239. doi:10.4141/CJSS09040

VanderZaag, A.C., R.J. Gordon, R.C. Jamieson, D.L. Burton, and G.W. Stratton. 2010b. Permeable synthetic covers for controlling emissions from liquid dairy manure. Appl. Eng. Agric. 26:287-297. doi:10.13031/2013.29544

Webb, J., S.G. Sommer, T. Kupper, K. Groenestein, N.J. Hutchings, B. EurichMenden, L. Rodhe, T.H. Misselbrook, and B. Amon. 2012. Emissions of ammonia, nitrous oxide, and methane during the management of solid manures. In: E. Lichtfouse, editor, Agroecology and strategies for climate change. Sustainable Agriculture Reviews 8. Springer, Dordrecht, the Netherlands. p. 67-107.

Wood, J.D., R.J. Gordon, C. Wagner-Riddle, K.E. Dunfield, and A. Madani. 2012. Relationships between dairy slurry total solids, gas emissions, and surface crusts. J. Environ. Qual. 41:694-704. doi:10.2134/jeq2011.0333 